\title{
Variation in Crop Developmental Rate of Grass Pea in Relation to the Agro-Climatic Factors
}

\author{
A. Ghosh", S.A. Khan and M.K. Nanda \\ Department of Agricultural Meteorology and Physics, Bidhan Chandra Krishi \\ Viswavidyalaya-741 252, West Bengal, India \\ *Corresponding author
}

Keywords

Correlation, Crop Developmental rate, Grass pea, Phenological stage, Regression

Article Info

Accepted:

17 January 2018

Available Online:

10 February 2018

\section{A B S T R A C T}

One field experiment was conducted in the winter season of the year 2016-2017 to determine the effects of agro-climatic factors on crop developmental rate (CDR) of grass pea (Lathyrus sativus L.). CDR of a phenological stage is simply the reciprocal of the duration of that particular stage. Grass pea (variety: 'Prateek') was sown on nine different dates $\left(26^{\text {th }}\right.$ October, $2^{\text {nd }}$ November, $9^{\text {th }}$ November, $16^{\text {th }}$ November, $23^{\text {rd }}$ November, $30^{\text {th }}$ November, $7^{\text {th }}$ December, $14^{\text {th }}$ December and $21^{\text {st }}$ December). Entire crop growing period was divided into four phenological stages viz. vegetative stage, reproductive stage, pod developmental stage and maturity stage. CDR during vegetative stage showed decreasing trend while during the later three stages CDR were found to increase gradually from first date of sowing to the last date of sowing. Results showed that Growing degree day (GDD), Heliothermal units (HTU) were positively correlated with CDR. Air and soil temperatures played significant beneficial role on CDR. Regression equations were developed by using SPSS 16.0 version for prediction of CDR. Regression analysis showed that the linear equations involving morning actual vapour pressure during reproductive phase and diurnal temperature range during maturity stage which could explain $98 \%$ and $98.9 \%$ of the total variability in CDR respectively.

\section{Introduction}

Development of a crop during its life cycle is greatly influenced by the agroclimatic factors. Entire crop developmental period can be divided into several phenological stages.

A certain temperature and heat units are required by the crops to attain a certain phenological stages (Sikder, 2009). Effect of air temperature on crop phenology can be determined by studying the accumulation of heat units (Rajput et al., 1987). Durations of the phenological stages depend on mean and accumulated weather parameters and agrometeorological indices. Durations of the phenological stages were altered with the sowing time (Kumar et al., 2008). Reciprocal of the duration of a certain phenological stage is the rate of development during that particular stage. Grass pea is an important grain legume and it can thrive well in adverse weather conditions. This study was conducted to investigate how development of this crop 
was influenced by different agro-climatic factors.

\section{Materials and Methods}

One field experiment was conducted at Instructional Farm $\left(22^{\circ} 58^{\prime} \mathrm{N}\right.$ and 88 $\left.31^{\prime} \mathrm{E}\right)$, Bidhan Chandra Krishi Viswavidyalaya, West Bengal during winter season of 2016-2017 with grass pea (variety: 'Prateek') sown on nine dates $\left(26^{\text {th }}\right.$ October, $2^{\text {nd }}$ November, $9^{\text {th }}$ November, $16^{\text {th }}$ November, $23^{\text {rd }}$ November, $30^{\text {th }}$ November, $7^{\text {th }}$ December, $14^{\text {th }}$ December and $21^{\text {st }}$ December). The experiment was carried out in Randomized complete block design (RCBD) with three replications. Recommended cultivation practices were followed. The entire growing period was divided into four stages viz. vegetative stage, reproductive stage, pod developmental stage and maturity stage. Crop developmental rate (CDR) during different phenological stages was calculated by the formula:

CDR $=1 \div$ duration (days) day $^{-1}$

Agro-meteorological indices i.e. Growing degree day (GDD) and Heliothermal units (HTU) were computed during all the phenological stages following the methods used earlier by Khan et al., Computation of agrometeorological indices:

Growing degree day $(\mathrm{GDD})=\left(\overline{\mathrm{T}}_{\mathrm{m}}-\mathrm{T}_{\mathrm{b}}\right)$

Helothermal unit $(\mathrm{HTU})=\left[\left(\overline{\mathrm{T}}_{\mathrm{m}}-\mathrm{T}_{\mathrm{b}}\right) \mathrm{x} \mathrm{BSH}\right]$

Where,

$\mathrm{BSH}=$ Bright sunshine hours (Hour)

$\mathrm{T}_{\mathrm{m}}=$ Daily mean temperature in ${ }^{\circ} \mathrm{C}$.

$\mathrm{T}_{\mathrm{b}}=$ Base temperature of $5^{\circ} \mathrm{C}$.

Mean photo and mean nycto temperatures were evaluated as per methods suggested by Venkataraman and Krishnan (1992).
Mean photo temperature $=$ maximum temperature - 0.40 (maximum temperature minimum temperature)

Mean nycto temperature $=$ minimum temperature +0.40 (maximum temperature minimum temperature)

Correlation studies were carried out between phenophase-wise mean and accumulated weather parameters and different agrometeorological indices and CDR following the method of Gomez and Gomez 1984. Best-fit regression equations were developed by stepwise regression through the SPSS 16.0 version for prediction of CDR.

\section{Results and Discussion}

\section{Crop Developmental Rate (CDR)}

CDR (day ${ }^{-1}$ ) during different phenological stages of grass pea sown under nine different dates has been presented in table 1. CDR of vegetative phase varied from its highest value of $0.0286 \mathrm{day}^{-1}$ in the crop sown on $26^{\text {th }}$ October to the lowest value of $0.0217 \mathrm{day}^{-1}$ in crop sown on $23^{\text {rd }}$ November.

CDR of vegetative stage showed a decreasing trend from $26^{\text {th }}$ October sown crop to $23^{\text {rd }}$ November sown crop and then CDR showed an increasing trend up to $21^{\text {st }}$ December sown crop.

During reproductive, pod developmental and maturity stages CDR showed rising trend from the lowest values in $26^{\text {th }}$ October sown crop (reproductive stage: 0.0118 day $^{-1}$; pod developmental stage: 0.0130 day $^{-1}$ and maturity stage: $0.0400 \mathrm{day}^{-1}$ ) to the highest values in $21^{\text {st }}$ December sown crop (reproductive stage: 0.0189 day $^{-1}$; pod developmental stage: 0.0213 day $^{-1}$ and maturity stage: 0.0714 day $^{-1}$ ). Results indicated that with delayed sowing crop 
developmental rate increased which indicated the shortening of the durations of the phenological stages which is in agreement with the results found by Haider et al., (2003).

\section{Effect of agro-climatic factors on CDR}

In order to assess the effect of agro-climatic factors on CDR correlation studies were carried out and the values of correlation coefficients (r) have been presented in table 2 and table 3. CDR during a phenological stage was correlated with the agro-climatic factors prevailing during that particular stage. Results revealed that CDR was negatively correlated with Growing degree day (GDD) and Heliothermal units (HTU) accumulated during reproductive, pod developmental and maturity stages. GDD showed highest correlation $(r=-$ $\left.0.95^{* *}\right)$ with CDR during maturity stage while HTU showed highest correlation $(r=-0.92 * *)$ with CDR during reproductive stage.

Average photo temperature and nycto temperature during all growth stages exhibited positive correlations with CDR. Highest correlation was found between average photo and nycto temperatures and CDR during reproductive stage of the crop. Correlation studies also showed that bright sunshine hours (BSH) accumulated during every stage had adverse effect on CDR (table 3). Total rainfall during the phenological stages played beneficial role on CDR as shown by the values of correlation coefficients.

On the other hand total evaporation played beneficial role on CDR during vegetative and reproductive stages while during pod developmental and maturity stages CDR was adversely affected by total evaporation. Average maximum, minimum and mean temperature during all phenological stages exhibited significant positive correlations with CDR while diurnal temperature range during vegetative, pod developmental and maturity stages had adverse effects on CDR. Mean relative humidity showed negative correlations with CDR during first three phenological stages i.e. vegetative, reproductive and pod developmental stages. Morning vapour pressure, afternoon vapour pressure and mean vapour pressure exhibited positive associations with CDR during all the phenological stages. Same results were found for vapour pressure deficit also except during maturity stage. Correlation studies indicated that morning, afternoon and mean soil temperature at $5 \mathrm{~cm}, 15 \mathrm{~cm}$ and $30 \mathrm{~cm}$ depths played significant beneficial role on CDR during every phenological stage (table 3).From the results it was clear that as the temperature increased during different phenological stages, crop development became faster. Shortening of the duration in phenological stages were demonstrated earlier in wheat by Sandhu et al., (1999) and Ghosh et al., (2000).

\section{Prediction of CDR}

Regression analysis (table 4) showed that in model 1, the estimated linear regression involving morning actual vapour pressure during reproductive stage, was significant at $1 \%$ level of significance, wherein the adjusted $\mathrm{R}^{2}$ of the model was 0.980 which indicated that the model was able to account for $98 \%$ of the total variability in the total duration of grass pea.In model 2 , the computed linear regression model is found to be significant at $1 \%$ level of significance with adjusted $\mathrm{R}^{2}$ of 0.989 . Thus, it indicated that $98.9 \%$ of the total variability in the total duration could be explained by a linear function which included morning actual vapour pressure during reproductive stageand diurnal temperature difference during maturity stage. Thus diurnal temperature difference during maturity stage and vapour pressure during reproductive stage were very important factors influencing duration of the crop. 
Table.1 Variation in crop developmental rate (CDR) under different dates of sowing

\begin{tabular}{|l|c|c|c|c|}
\hline \multicolumn{1}{|c|}{$\begin{array}{c}\text { Dates of } \\
\text { Sowing }\end{array}$} & $\begin{array}{c}\text { Vegetative } \\
\text { stage }\end{array}$ & $\begin{array}{c}\text { Reproductive } \\
\text { stage }\end{array}$ & $\begin{array}{c}\text { Pod developmental } \\
\text { stage }\end{array}$ & Maturity stage \\
\hline $\mathbf{2 6 ^ { \text { th } }}$ October & 0.0286 & 0.0118 & 0.0130 & 0.0400 \\
\hline $\mathbf{2}^{\text {nd }}$ November & 0.0270 & 0.0125 & 0.0139 & 0.0435 \\
\hline $\mathbf{9}^{\text {th }}$ November & 0.0263 & 0.0127 & 0.0145 & 0.0526 \\
\hline $\mathbf{1 6}^{\text {th }}$ November & 0.0244 & 0.0143 & 0.0169 & 0.0769 \\
\hline $\mathbf{2 3}^{\text {rd }}$ November & 0.0217 & 0.0156 & 0.0189 & 0.0667 \\
\hline $\mathbf{3 0}^{\text {th }}$ November & 0.0222 & 0.0164 & 0.0192 & 0.0769 \\
\hline $\mathbf{7}^{\text {th }}$ December & 0.0233 & 0.0182 & 0.0208 & 0.0714 \\
\hline $\mathbf{1 4}^{\text {th }}$ December & 0.0238 & 0.0179 & 0.0204 & 0.0714 \\
\hline $\mathbf{2 1}^{\text {th }}$ December & 0.0244 & 0.0189 & 0.0213 & 0.0714 \\
\hline C.D. $\mathbf{( 5 \% )}$ & 0.0246 & 0.0153 & 0.0177 & 0.0634 \\
\hline S.E.m. $\mathbf{( \pm )}$ & 0.0023 & 0.0027 & 0.0032 & 0.0143 \\
\hline C.V. $\mathbf{( \% )}$ & 9.1840 & 17.4219 & 18.0435 & 22.5034 \\
\hline
\end{tabular}

Table. 2 correlation coefficients (r) between Crop developmental rate (CDR) and different agroclimatic factors

\begin{tabular}{|l|}
\multicolumn{1}{|c|}{ Agro-climatic factors } \\
\hline Growing degree days \\
\hline Bright sunshine hours \\
\hline Heliothermal units \\
\hline Rainfall \\
\hline Evaporation \\
\hline Maximum temperature \\
\hline Minimum temperature \\
\hline Mean temperature \\
\hline Diurnal temperature difference \\
\hline Morning relative humidity \\
\hline Afternoon relative humidity \\
\hline Mean relative humidity \\
\hline Photo temperature \\
\hline Nycto temperature \\
\hline Morning vapour pressure \\
\hline Afternoon vapour pressure \\
\hline Mean vapour pressure \\
\hline $\begin{array}{l}\text { Morning vapour pressure } \\
\text { deficit }\end{array}$ \\
\hline $\begin{array}{l}\text { Afternoon vapour pressure } \\
\text { deficit }\end{array}$ \\
\hline Mean vapour pressure deficit \\
\hline
\end{tabular}

\begin{tabular}{|c|c|c|c|}
\hline $\begin{array}{c}\text { Vegetative } \\
\text { stage }\end{array}$ & $\begin{array}{c}\text { Reproductive } \\
\text { stage }\end{array}$ & $\begin{array}{c}\text { Pod developmental } \\
\text { stage }\end{array}$ & $\begin{array}{c}\text { Maturity } \\
\text { stage }\end{array}$ \\
\hline 0.33 & -0.93 & -0.89 & -0.95 \\
\hline-0.05 & -0.98 & -0.98 & -0.93 \\
\hline 0.62 & -0.92 & -0.86 & -0.81 \\
\hline 0.79 & 0.92 & 0.87 & 0.36 \\
\hline 0.22 & 0.14 & -0.40 & -0.96 \\
\hline 0.89 & 0.97 & 0.94 & 0.52 \\
\hline 0.84 & 0.98 & 0.97 & 0.63 \\
\hline 0.87 & 0.98 & 0.97 & 0.60 \\
\hline-0.70 & 0.20 & -0.26 & -0.69 \\
\hline-0.90 & -0.20 & -0.16 & 0.39 \\
\hline 0.38 & -0.63 & -0.35 & 0.71 \\
\hline-0.08 & -0.43 & -0.25 & 0.67 \\
\hline 0.87 & 0.98 & 0.96 & 0.60 \\
\hline 0.86 & 0.98 & 0.97 & 0.62 \\
\hline 0.85 & 0.96 & 0.96 & 0.64 \\
\hline 0.77 & 0.82 & 0.89 & 0.65 \\
\hline 0.81 & 0.93 & 0.94 & 0.64 \\
\hline 0.78 & 0.82 & 0.98 & -0.15 \\
\hline 0.89 & 0.98 & 0.99 & -0.47 \\
\hline 0.89 & 0.99 & 0.99 & -0.49 \\
\hline
\end{tabular}


Table.3 Correlation coefficients (r) between crop developmental rate (CDR) and soil temperatures at different depths

\begin{tabular}{|l|c|c|c|c|}
\hline \multicolumn{1}{|c|}{ Soil temperatures } & $\begin{array}{c}\text { Vegetative } \\
\text { stage }\end{array}$ & $\begin{array}{c}\text { Reproductive } \\
\text { stage }\end{array}$ & $\begin{array}{c}\text { Pod developmental } \\
\text { stage }\end{array}$ & $\begin{array}{c}\text { Maturity } \\
\text { stage }\end{array}$ \\
\hline $\begin{array}{l}\text { Morning soil temperature } \\
\text { at 5 cm depth }\end{array}$ & 0.87 & 0.98 & 0.98 & 0.73 \\
\hline $\begin{array}{l}\text { Morning soil temperature } \\
\text { at 15 cm depth }\end{array}$ & 0.87 & 0.98 & 0.97 & 0.73 \\
\hline $\begin{array}{l}\text { Morning soil temperature } \\
\text { at 30 cm depth }\end{array}$ & 0.87 & 0.97 & 0.96 & 0.78 \\
\hline $\begin{array}{l}\text { Afternoon soil temperature } \\
\text { at 5 cm depth }\end{array}$ & 0.89 & 0.98 & 0.98 & 0.73 \\
\hline $\begin{array}{l}\text { Afternoon soil temperature } \\
\text { at 15 cm depth }\end{array}$ & 0.89 & 0.98 & 0.98 & 0.74 \\
\hline $\begin{array}{l}\text { Afternoon soil temperature } \\
\text { at 30 cm depth }\end{array}$ & 0.87 & 0.97 & 0.96 & 0.75 \\
\hline $\begin{array}{l}\text { Mean soil temperature at 5 } \\
\text { cm depth }\end{array}$ & 0.88 & 0.98 & 0.98 & 0.73 \\
\hline $\begin{array}{l}\text { Mean soil temperature at } \\
\text { 15 cm depth }\end{array}$ & 0.88 & 0.98 & 0.97 & 0.74 \\
\hline $\begin{array}{l}\text { Mean soil temperature at } \\
\text { 30 cm depth }\end{array}$ & 0.87 & 0.97 & 0.96 & 0.76 \\
\hline
\end{tabular}

Table.4 Regression equations for prediction of crop developmental rate (CDR)

\section{Model no.}

1

\section{Regression equations}

$$
\begin{aligned}
& \mathrm{Y}=177.761 * *-4.110^{* *} \mathrm{X}_{1} \\
& \mathrm{Y}=152.883 * *-3.565^{* *} \mathrm{X}_{1}+1.097 \mathrm{X}_{2}
\end{aligned}
$$

\section{\begin{tabular}{l|l} 
Adjusted R2 & Std. error of the estimate
\end{tabular}}

\begin{tabular}{|l|l|}
\hline $0.980 * *$ & 1.219 \\
\hline $0.989 * *$ & 0.929
\end{tabular}

CDR in the later stages of crop development increased with delay in sowing. CDR during different phenological stages were greatly influenced by air temperature vapour pressure and vapour pressure deficit.

During vegetative stage GDD and HTU exhibited positive association with CDR while these two agrometeorological indices showed negative association with CDR during the later stages. CDR could be predicted by using morning vapour pressure during reproductive stage and diurnal temperature difference during maturity stage as predictable variables.

\section{Acknowledgement}

The fund supported by the Directorate of Farms, Bidhan Chandra Krishi Viswavidyalaya, Mohanpur, Nadia, West Bengal, India in carrying out this research is greatly acknowledged.

\section{References}

Ghosh, D. C., Nandi, P. and De, B. 2000.Phenological development and productivity of wheat (Triticum aestivum L.) at different dates of 
sowing.Indian J. Agric. Sci,. 70(6): 390395.

Gomez, K. A. and Gomez, A. A. 1984.Statistical Procedures for Agricultural Research (2nd Edition). John Wiley \& Sons, New York, pp. 680.

Haider, S. A., Alam, M.Z. and Paul,N. K. 2003. Influence of different sowing dates on the phenology and accumulated heat units in wheat. Journal of bilogical sciences, 3 (10): 932-939

Khan, S. A., Maity, G. C. and Das, L. 2005. Prediction of grain yield of kharif rice based on thermal, heliothermal and photothermal units prevailing during different phases of growth. Environment and Ecology, 23(3): 545-552.

Kumar, A., Pandey, V., Shekh, A.M. and Kumar, M. 2008. Growth and Yield Response of Soybean (Glycine max L.) in Relation to Temperature, Photoperiod and Sunshine Duration at Anand, Gujarat, India. American-Eurasian Journal of Agronomy, 1 (2): 45-50.
Mcnaughton, H.G., Warrington, I.J. and Turnbulk, H.L. 1985. The effects of temperature and day length on the rate of development of pigeanpea. Annal Bot., 56(5): 597-611.

Rajput, R. P., Deshmukh, M. R. and Paradkar V. K. 1987.Accumulated heat unit and phenology relationships in wheat (Triticum aestivum L.) as influenced by planting dates under late sown conditions.J. Agron. Crop Sci., 159:345- 348.

Sandhu, I. S., Sharma, A. R. and Sur, H. S. 1999. Yield performance and heat unit requirement of wheat (Triticum aestivum L.) varieties as affected by sowing dates under rain fed conditions. Indian J. Agric. Sci, 69: 175-179.

Sikder, S.2009. Accumulated Heat Unit and Phenology of Wheat Cultivars as Influenced by Late Sowing Heat Stress Condition. J Agric Rural Dev, 7(1\&2): 57-64

Venkataraman, S. and Krishnan, A. 1992. Crops and Weather. Indian Council of Agricultural Research, Pusa, New Delhi, pp. 302.

\section{How to cite this article:}

Ghosh, A., S.A. Khan and Nanda, M.K. 2018. Variation in Crop Developmental Rate of Grass Pea in Relation to the Agro-Climatic Factors. Int.J.Curr.Microbiol.App.Sci. 7(02): 1727-1732. doi: https://doi.org/10.20546/ijcmas.2018.702.209 